Diabetologia 7, 339-348 (1971)

(C) by Springer-Verlag 1971

\title{
Monoamines in the Pancreatic Islets of the Mouse*
}

\author{
Subcellular Localization of 5-hydroxytryptamine by Electron Microscopic Autoradiography
}

\author{
R. Ekrorm, L.E. Ericson and I. Lundquist
}

Department of Anatomy, University of Göteborg, and Department of Pharmacology, University of Lund, Sweden

Received: April 3, 1971

Summary. By application of autoradiographic technique the cellular and subcellular distribution of radio. activity in mouse pancreatic islets was investigated following intravenous administration of ${ }^{3} \mathrm{H}-5$-hydroxytryptophan. Autoradiographic silver grains, most of which probably represent 5-hydroxytryptamine formed from the labelled precursor, appeared over $A_{2}$ and $B$ cells, whereas very few grains were recorded over $A_{1}$ cells at any time investigated $(20 \mathrm{~min}-16$ hours $)$ and also when monoamine oxidase was inhibited. Quantitative analysis of autoradiographic sections revealed that the concentration of silver grains over the specific granules of $\mathrm{A}_{2}$ and $B$ cells was 5-10 times higher than over the remaining parts of these cells. In $A_{2}$ cells the highest grain count was recorded at 20 minutes, in $B$ cells at 1 hour after the injection of label. After 8 hours very few, and after 16 hours no silver grains appeared over islet cells. Inhibi tion of monoamine oxidase caused an increased retention of label over islet cells, most pronounced over $\mathrm{A}_{2}$ cells. Pretreatment with reserpine abolished the autoradiographic reaction.

Monoamines dans les îlots pancréatiques de la souris

Résumé. En appliquant la technique autoradiographique, on a étudié la distribution cellulaire et subcellulaire de la radioactivité dans les îlots pancréatiques de la souris après une injection intra-veineuse de ${ }^{3} \mathrm{H}-5$-hydroxytryptophane. Des grains d'argent autoradiographiques dont la plupart représentent probablement de la 5-hydroxytryptamine qui s'est formée à partir du précurseur marqué, sont apparus sur les cellules $A_{2}$ et $B$, tandis que très peu de grains ont été trouvés sur les cellules $A_{1}$ à chacun des examens (entre $20 \mathrm{~min}$ et $16 \mathrm{~h}$ ) et de même après l'inhibition de la monoamine-oxidase. L'analyse quantitative des coupes autoradiographiques a révélé que la concentration de grains d'argent sur les granules spécifiques des cellules $A_{2}$ et $B$ était 5 à 10 fois plus élevée que sur les parties restantes de ces cellules. Sur les cellules $\bar{A}_{2}$ le nombre le plus élevé de grains a été noté $20 \mathrm{~min}$ après l'injection du marqueur et sur les cellules B une heure après cette injection. Au bout de $8 \mathrm{~h}$, il n'apparaissait que très peu de grains d'argent sur les cellules des îlots, et plus aucun au bout de $16 \mathrm{~h}$. L'inhibition de la monoamine-oxidase a provoqué une augmentation de la rétention de marqueur sur les cellules des îlots, plus prononcée sur les cellules $A_{2}$. Un traitement préalable à la réserpine a supprimé cette réaction autoradiographique.

\section{Monoamine in den Pankreasinseln der Maus}

Zusammenfassung. Mit Hilfe der Technik der Autoradiographie wurde die zelluläre und subzelluläre Verteilung der Radioaktivität nach intravenöser Applikation von ${ }^{3} \mathrm{H}-5$-Hydroxytryptophan in den Pankreasinseln der Maus untersucht. Die autoradiographischen Silberkörner, welche zumeist 5-Hydroxytryptamin darstellen, das aus der radioaktiven Ausgangssubstanz gebildet worden war, erschienen über den $\mathrm{A}_{2}$ und B-Zellen, während nach jedem untersuchten Zeitintervall (20 min - $16 \mathrm{Std}$ ) auch wenn die Monoamino-Oxidase gehemmt wurde, nur sehr wenige Körner über den $A_{1}$-Zellen erschienen. Quantitative Untersuchungen der Autoradiographieschnitte zeigten, daß die Konzentration der Silberkörner über den spezifischen Granula der $\mathrm{A}_{2}$-Zellen und der B-Zellen etwa 5-10 mal höher als über den restlichen Teilen der Zellen war. In den $\mathrm{A}_{2}$-Zellen wurde die höchste Körnerkonzentration nach $20 \mathrm{~min}$, in den B-Zellen 1 Std nach Injektion der markiorten Substanz festgestellt. Nach 8 Std zeigten sich nur wenige, nach $16 \mathrm{Std}$ keine Silberkörner mehr über den Inselzellen. Die Hemmung der Monoamino-Oxidase verursachte eine vermehrte Anreicherung von Radioaktivität über den Inselzellen, am meisten über den A.-Zellen. Eine Vorbehandlung mit Reserpin verhinderte die autoradiographische Darstellung.

Key-words: Autoradiography, 5-hydroxytryptamine, 5-hydroxytryptophan, monoamine oxidase inhibition, mouse, pancreatic islets, reserpine, ultrastructure.
Recent fluorescence-microscopic studies have revealed stores of 5 -hydroxytryptamine $(5$-HT) and dopamine (DA) in the pancreatic islets of several species $[6-8,16,17]$. In the mouse islet cells, however, monoamines can be demonstrated only provided that the appropriate amine precursors, as 5-hydroxytryptophan (5-HTP) and dihydroxyphenylalanine (DOPA), are administered. As shown with fluorescence microscopy $[6,8]$ as well as with light-microscopic autoradiography $[21,32]$, these amino acids are taken up

* This study was supported by Grant K71-12X3352-01 from the Swedish Medical Research Council. by islet cells and are then decarboxylated to the corresponding amines, which are stored for several hours in the cytoplasm.

Earlier studies at the light microscopic level furnished limited information about the precise cellular as well as subcellular localization of exogenous amines in mouse pancreatic islets. Such knowledge should be essential for the understanding of the physiological significance of monoaminergic mechanisms operating in endocrine cells. This report presents a study of the localization of ${ }^{3} \mathrm{H}-5-\mathrm{HT}$, formed from the administered precursor ${ }^{3} \mathrm{H}-5$-HTP, in mouse islet cells by means of 
electron-microscopic autoradiography. In a subsequent paper [11] the possible functional implications of some of the morphological observations presented here will be discussed.

\section{Materials and Methods}

The study was performed on 20 albino mice (Anticimex, Sweden) weighing $20-25 \mathrm{~g}$. Sixteen of them were used for electron-microseopic autoradiography. The animals were maintained under ordinary laboratory conditions, and fed on a standard diet of pellets and water ad libitum.

For autoradiography the mice were injected intravenously in the tail with $1.5 \mathrm{mCi}$ of ${ }^{3} \mathrm{H}-\mathrm{DL}-5$-HTP (specific activity $1860 \mathrm{mCi} / \mathrm{mmole}$, Radiochemical Centre, Amersham, England). The pancreatic glands were fixed by perfusion with glutaraldehyde via the ascending aorta, $20 \mathrm{~min}$ (4 animals), $1 \mathrm{~h}$ (2 animals), $2 \mathrm{~h}$ ( 3 animals), $8 \mathrm{~h}(1$ animal) and $16 \mathrm{~h}$ ( 1 animal) after the administration of the label. Four animals were given an inhibitor of monoamine oxidase (MAO), Pargyline hydrochloride (MO 911, Abbot Lab., $200 \mathrm{mg} /$ $\mathrm{kg}$ ), intraperitoneally $2 \mathrm{~h}$ prior to the injection of the label, and the pancreatic glands were fixed by perfusion $2 \mathrm{~h}$ (3 animals) and $16 \mathrm{~h}$ (1 animal) later. One animal received Reserpine (Ciba, $5 \mathrm{mg} / \mathrm{kg}$ ) $16 \mathrm{~h}$ before the administration of the label, and the pancreas was fixed $2 \mathrm{~h}$ later. Four animals not injected with label served as controls.

The perfusion solution consisted of $3 \%$ glutaraldehyde buffered with $0.075 \mathrm{M}$ sodium cacodylate, $\mathrm{pH}$ 7.2. After the perfusion of $50 \mathrm{ml}$, the splenic part of the pancreas was dissected out and cut into small pieces, which were immediately transferred to $1 \%$ osmium tetroxide in blood-isotonic Veronal acetate buffer, pH 7.2. The postfixation lasted for $2 \mathrm{~h}$. After dehydration in ethanol the tissue was embedded in Epon. Islet tissue was identified by light microscopy in sections $1 \mu$ thick. For autoradiography, pale-golden sections were out on an LKB Ultrotome, picked up on Formvar-coated copper grids, stained with uranyl acetate and lead citrate and then covered with a layer of carbon by vacuum evaporation. The emulsion, Ilford L 4, was applied to the sections by means of a wire loop [5, 27]. Most grids, and all grids used for quantitative analysis of silver grain distribution, were developed after 6 weeks in Kodak D 19 B (2 min) and fixed in Kodak F-24 fixer ( $2 \mathrm{~min}$ ).

For quantitative analysis, all cells occurring in the periphery of at least 2 islets from each mouse were photographed at a magnification of $\times 6000$. The electron micrographs were enlarged 3 times in printing. On each paper copy the areas occupied by the different types of islet cells as well as the areas occupied by their specific granules and the remaining parts of the cells were calculated. This was done by placing, on top of the paper copy, a squared lattice (square size $10 \times$ $10 \mathrm{~mm}$ ) and counting the number of intersections over these areas. Then the numbers of silver grains overlying specific granules and remaining cytoplasm and nucleus were counted. The location of a grain was considered as the centre of the smallest circle necessary to circumscribe the grain. From these countings the average number of grains per unit section area was caloulated

\section{Results}

Ultrastructure. The ultrastructure of pancreatic islets in the mice injected with the radioactive 5-HTP did not deviate from that found in the control mice. Nor did the preparation for autoradiography and the administration of MAO inhibitor or reserpine influence the electronmicroscopic picture.

Three distinct cell types were regularly observed in all islets examined: $A_{1}, A_{2}$ and $B$ cells.

$A_{1}$ cells were observed in all islets examined. The section area occupied by $A_{1}$ cells was about $25 \%$ of that occupied by $\mathrm{A}_{2}$ cells. Like $\mathrm{A}_{2}$ cells, $\mathrm{A}_{1}$ cells always occurred in the periphery of the islets. $A_{1}$ cells generally had an elongated cell shape (Fig. 1) with cytoplasmic extensions; cross-sections of such extensions, a few micra in diameter, were often encountered. The polyhedral or oval nucleus (Figs. 1, 4, 5) was found in the widest part of the cell together with the Golgi apparatus and the bulk of the rough endoplasmic reticulum. The latter had a limited extension, and consisted of flattened ribosome-studded cisternae, which were narrow and of uniform width (Fig. 4). The most characteristic feature of the $A_{1}$ cells was the granules; their mean diameter was $1900 \AA$ (total range $1100-3300 \AA$ ) and they comprised about $15 \%$ of the cell volume as revealed by the quantitative analysis of electron-microscopical sections. The granules, which were often confined to the cytoplasmic extensions, had a varying shape: spherical, oval kidney-shaped or polyhedral (Figs. 1, $4,5,6)$. Variations were noted in the morphology of the granules between different $A_{1}$ cells. Thus, in some cells the granules had a longer diameter than the average (Fig. 1); in other cells almost all the granules were spherical (Fig. 4), in contrast to the polymorphous population of granules generally seen in $A_{1}$ cells. The granules had a core of high electron density, similar to that of the $\mathrm{A}_{2}$ cell granules. The dense core was invested by a membrane, which was very closely applied to the core, the intervening electron-lucent rim being only about $100 \AA$ wide.

$A_{2}$ cells always occurred in the peripheral parts of the islets (Fig. 1) and made up about $10 \%$ of the endocrine cells. The $A_{2}$ cells were characterized by their spherical granules, which had a spherical core of very high density. The dense core was separated from the limiting membrane by a rim, about $400 \AA$ in width, which often contained a finely granular material of low electron density (Figs. 1, 6, 7). Most of the $\mathrm{A}_{2}$ cells had granules with a mean diameter of $3000 \AA$ (total range $2000-4000 \AA$ ) containing a dense core about $2200 \AA$ in diameter. A small percentage of the 


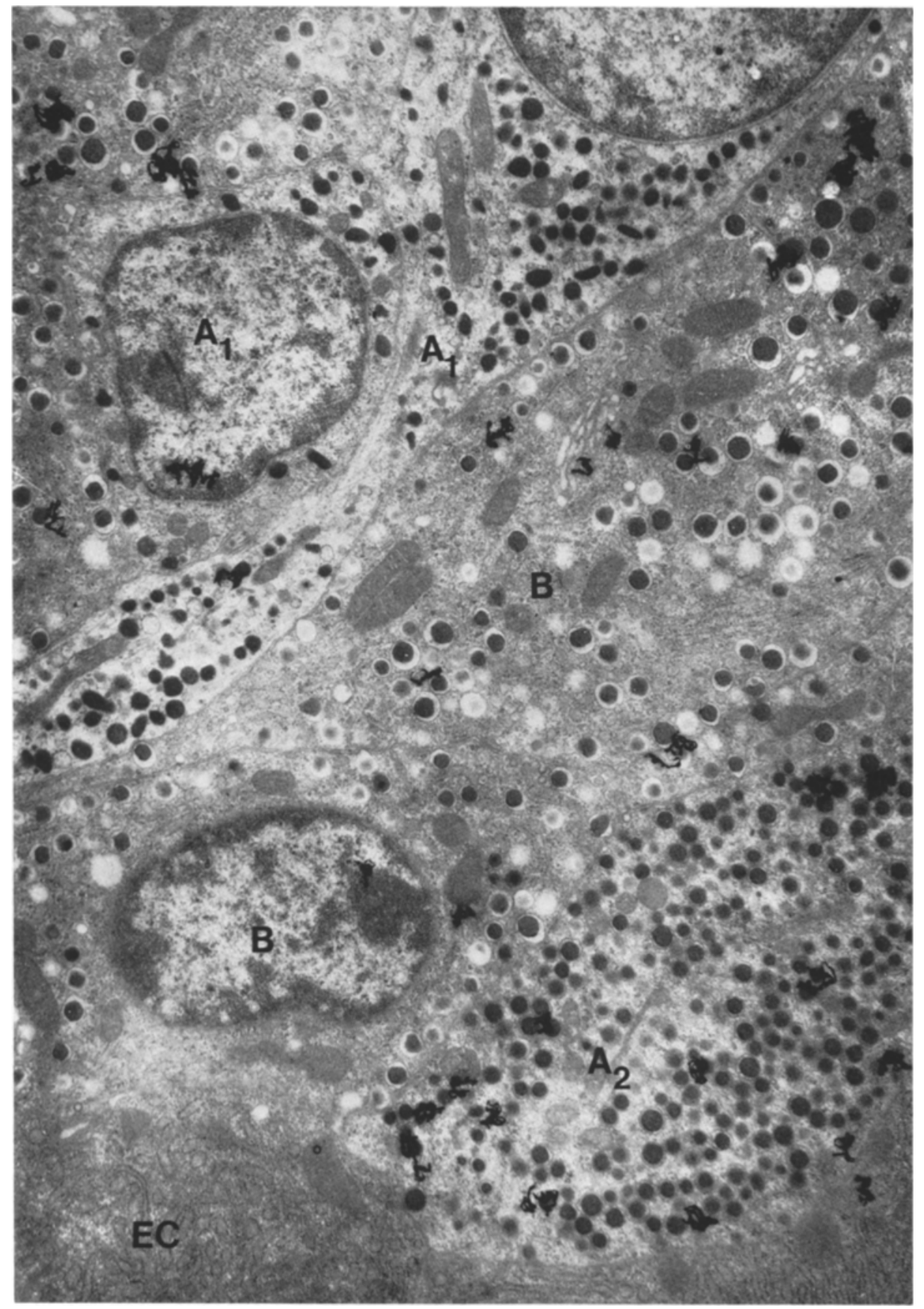

Fig. 1. Electron micrograph from the periphery of an islet, $2 \mathrm{~h}$ after injection of ${ }^{3} \mathbf{H}-5$-HTP. Two $A_{1}$ cells, containing comparatively large, polymorphous granules, as well as an $A_{2}$ and several $B$ cells can be distinguished. One $A_{1}$ cell has a typical cytoplasmic extension. Autoradiographic silver grains appear over $A_{2}$ and $B$ cells, whereas few grains can be seen over $A_{1}$ cells. EC-exocrine cell. $\times 14500$

$A_{2}$ cells had populations of granules that were either smaller (mean diameter $2500 \AA$ ) or larger (mean diameter $3300 \AA$ ) than the average granules. As revealed by quantitative analysis, the granules comprised about $15 \%$ of the cell volume of the $A_{2}$ cells.

$B$ cells were the predominant cell type in mouse islets and the only cell type observed in the central parts of the islets. The granules (mean diameter $3600 \AA$, range $2800-5000 \AA$ ) had a dense core (mean diameter $2200 \AA$, total range $1500-2800 \AA$ ) which was often located eccentrically (Figs. 1-7). The dense core, which had a spherical or polyhedral shape, was separated from the limiting membrane by a wide electronlucent space (Figs. 2, 3). In many granules the dense 


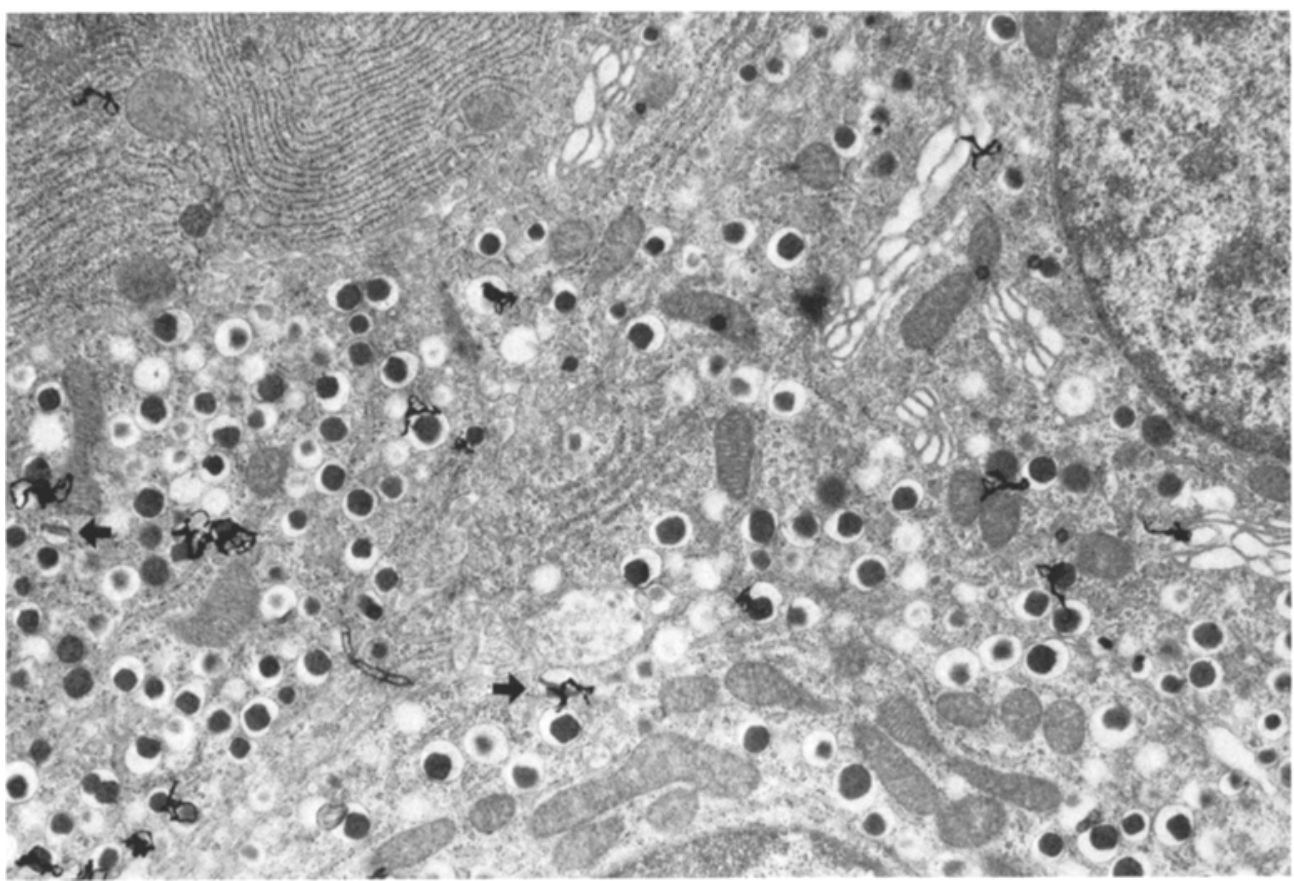

Fig. 2. Several B cells located in the periphery of an islet, $20 \mathrm{~min}$ after ${ }^{3} \mathrm{H}-5-\mathrm{HTP}$. Most of the silver grains are associated with the specific granules. Note crystal-like inclusions in some granules (arrows). $\times 10500$

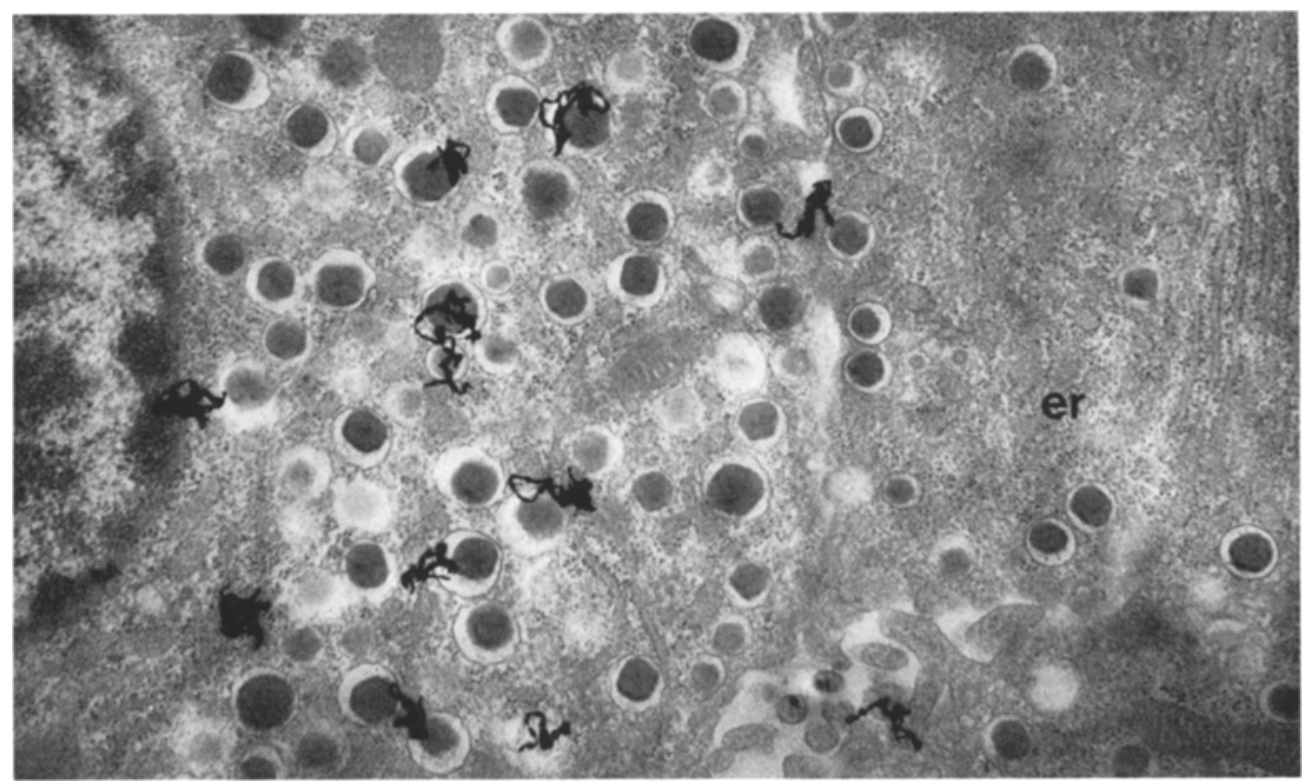

Fig. 3. Part of a B cell, $2 \mathrm{~h}$ after ${ }^{3} \mathrm{H}-5$-HTP. The silver grains are mainly associated with the specific granules. The cytoplasmic part containing endoplasmic reticulum (er) is devoid of autoradiographic reaction. $\times 24000$

core was replaced by a crystal-like inclusion (Fig. 2). The granules comprised on an average $30 \%$ of the volume of the $\mathrm{B}$ cells.

In our specimens only occasionally were cells encountered which could be classified as $\mathrm{D}$ cells $[3,4$, 28]. These cells were characterized by fairly large granules with a core of low electron density and a rather closely applied investing membrane.
Fairly often, sections through cells lacking granules were encountered. Without serial sectioning, which was not performed, it was impossible to classify these cells.

Autoradiography. After injection of ${ }^{3} \mathrm{H}-\mathrm{DL}-5-\mathrm{HTP}$, autoradiographic silver grains were observed over islet cells, exocrine cells $[10,21,32]$ and under certain conditions (after inhibition of MAO) also over adrenergic nerve terminals [14]. 
$A_{2}$ cells. As demonstrated by quantitative analysis, autoradiographic silver grains were recorded over the specific granules and over the remaining parts of the $A_{2}$ cells in about equal numbers. However, the number of grains per surface area was about 4 times higher over the specific granules at all times studied (Fig. 8). was detectable over $\mathrm{A}_{2}$ cells unless MAO was inhibited, which resulted in accumulation of grains over single, but not all $\mathrm{A}_{2}$ cells (Fig. 7). No difference was discernible in the concentration of silver grains between $A_{2}$ cells which differed with respect to the sizes of their granules.

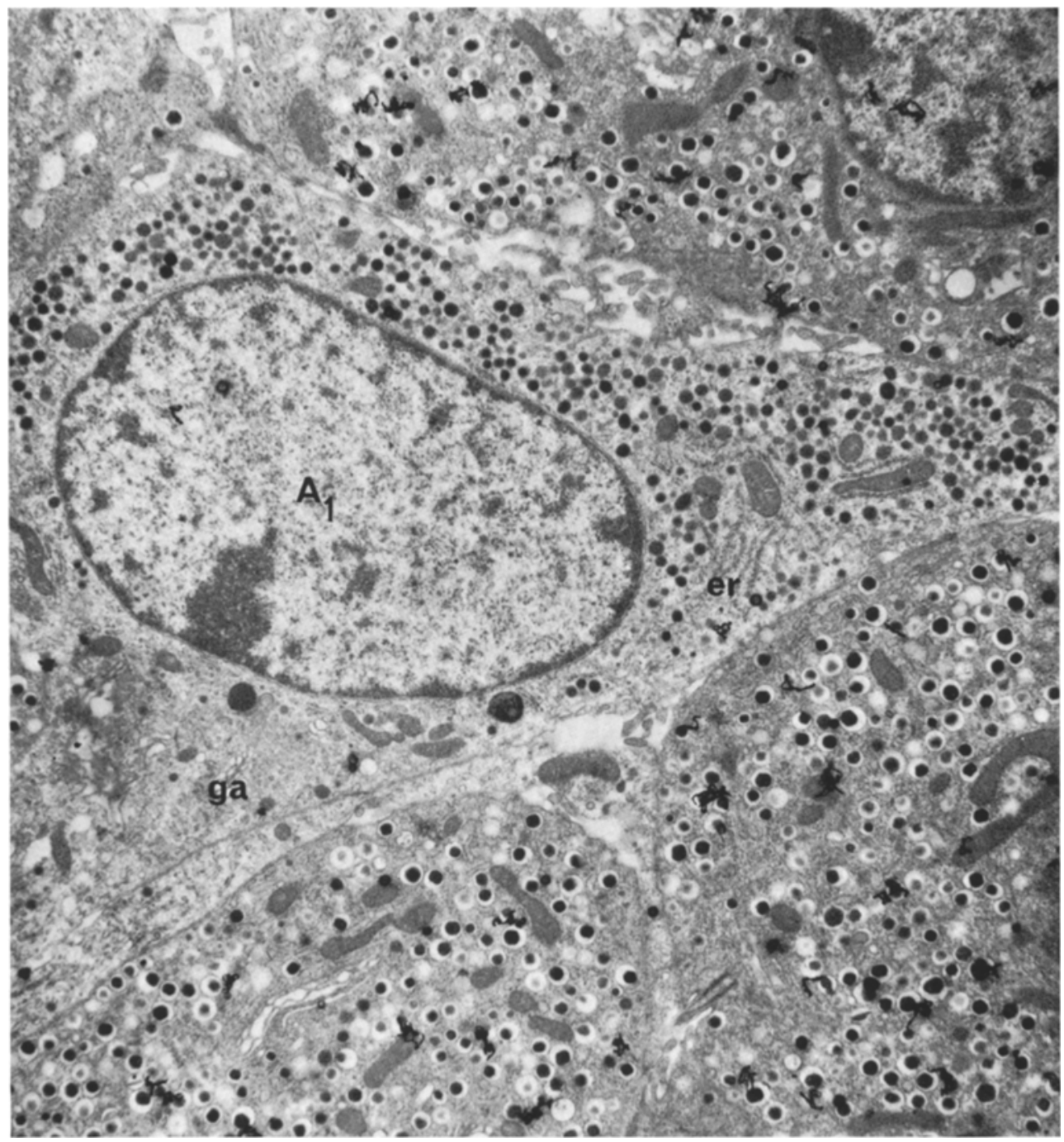

Fig. 4. Electron micrograph from a mouse $2 \mathrm{~h}$ after injection of label. Pretreatment with a monoamine oxidase inhibitor. The $A_{1}$ cell, containing mainly spherical granules, displays a very weak autoradiographic reaction, whereas the reaction over surrounding $B$ cells is pronounced. er-endoplasmic reticulum. ga-Golgi area. $\times 9000$

High grain counts were recorded already 20 min after administration of the label. Already at $1 \mathrm{~h}$ the number of silver grains had decreased and the counts were then gradually reduced at 2 and $8 \mathrm{~h}$ (Figs. 1, 8). Inhibition of MAO prior to the administration of the label caused an accumulation of silver grains over the $\mathrm{A}_{2}$ cells (Figs. 6, 8). In these animals the concentration of silver grains over the specific granules was many times higher than the corresponding concentration in mice not given an MAO-inhibitor (Fig. 8). Sixteen hours after administration of the label no autoradiographic reaction
$B$ cells. Over the $\mathrm{B}$ cells, the silver grains showed a preferential localization over the specific granules as demonstrated by quantitative analysis of autoradiographic sections (Fig. 9); at all times studied, most of the grains were recorded over the granules and the granular concentration exceeded the grain density over other cellular parts by 5-10 times. Indeed, over cytoplasmic areas devoid of specific granules and occupied by other cytoplasmic elements the silver grains were few (Fig. 3).

Already after $20 \mathrm{~min}$ high levels of radioactivity 


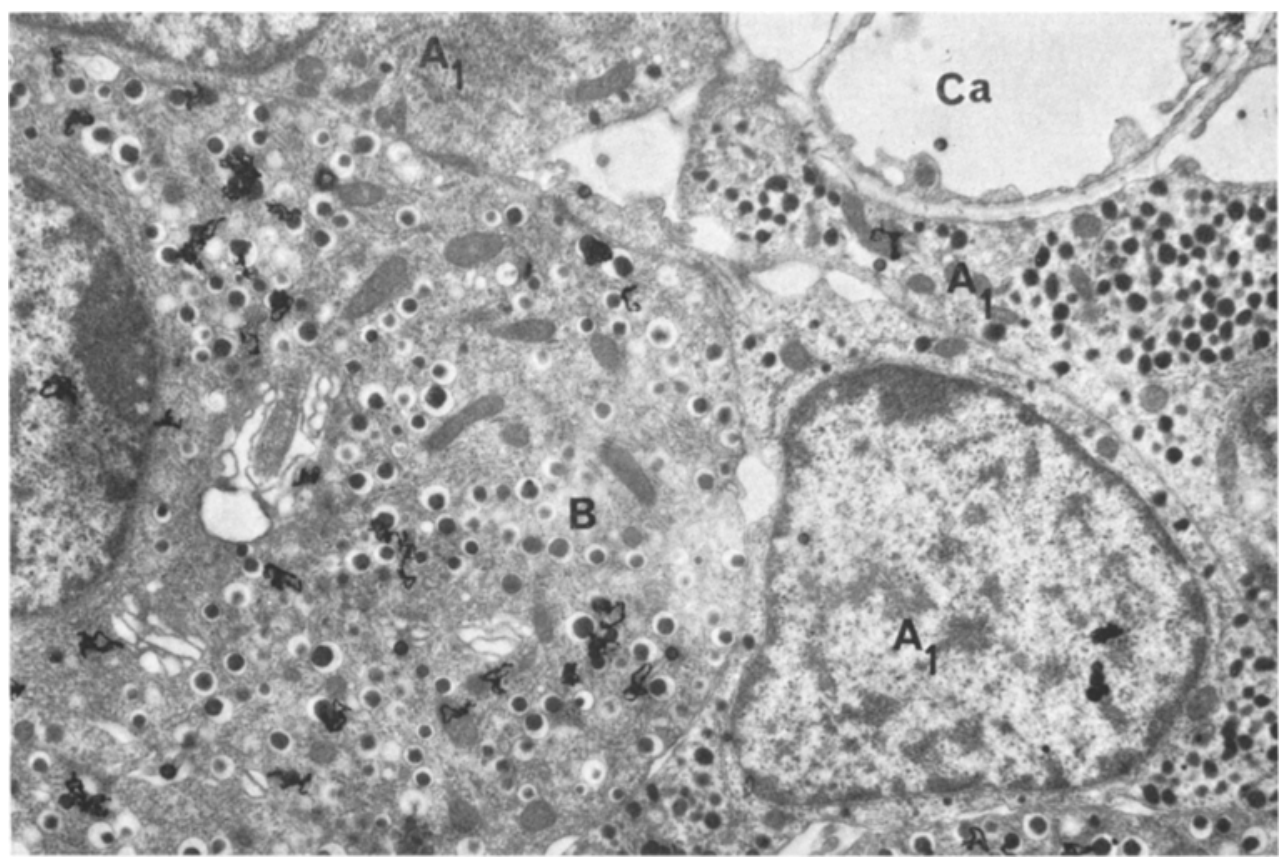

Fig. 5. Treatment the same as in Fig. 4. Parts of $3 A_{1}$ cells, with typical polymorphous granules. Few autoradiographic silver grains over $A_{1}$ cells compared with the number over $B$ cells. $\times 8500$

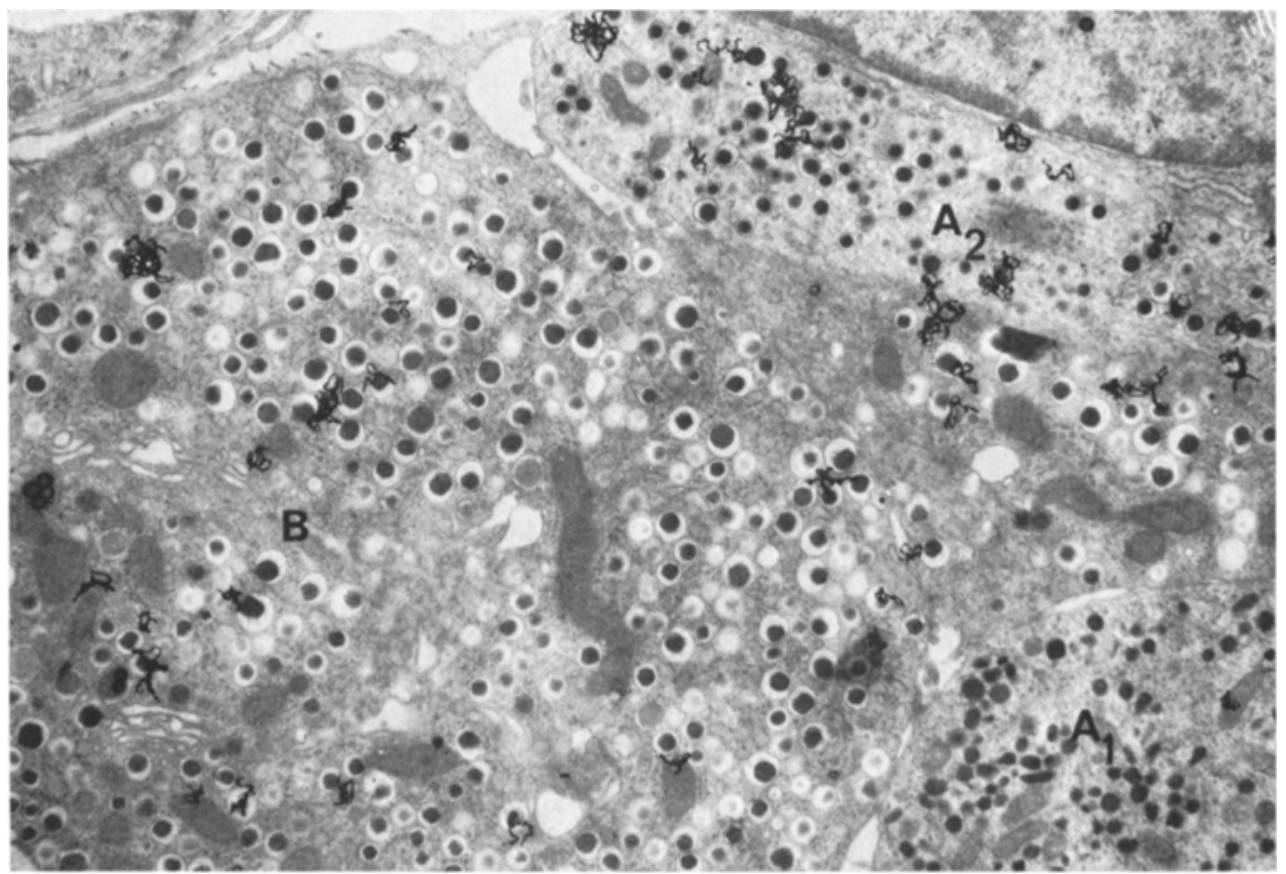

Fig. 6. The same treatment as in Figs. 4, 5. Silver grains appear over $A_{2}$ and $B$ cells but are few over $A_{1}$ cells. Cacapillary. $\times 9500$

were recorded over the B cells (Figs. 2, 9). One hour after the injection, the concentration of silver grains was still higher, whereas the concentration of silver grains over the $A_{2}$ cells reached its peak value by 20 min (cf. Figs. 8 and 9). At later observation times a gradual decrease of radioactivity was recorded over the B cells (Figs. 1, 9). Inhibition of MAO caused a rise in radioactivity as observed $2 \mathrm{~h}$ following the injection of the label (Figs. 4-6,9), but the effect of MAO-inhibition was not as marked as for $A_{2}$ cells 
(Figs. 8, 9). MAO-inhibition also caused persistence of the label in some, but not all $B$ cells at $16 \mathrm{~h}$ after the injection of ${ }^{3} \mathrm{H}-5$-HTP (Fig. 7). slightly higher labelling than the rest of the cytoplasm, whereas in others the reverse was found. The number of silver grains per surface area of the $A_{1}$ cells

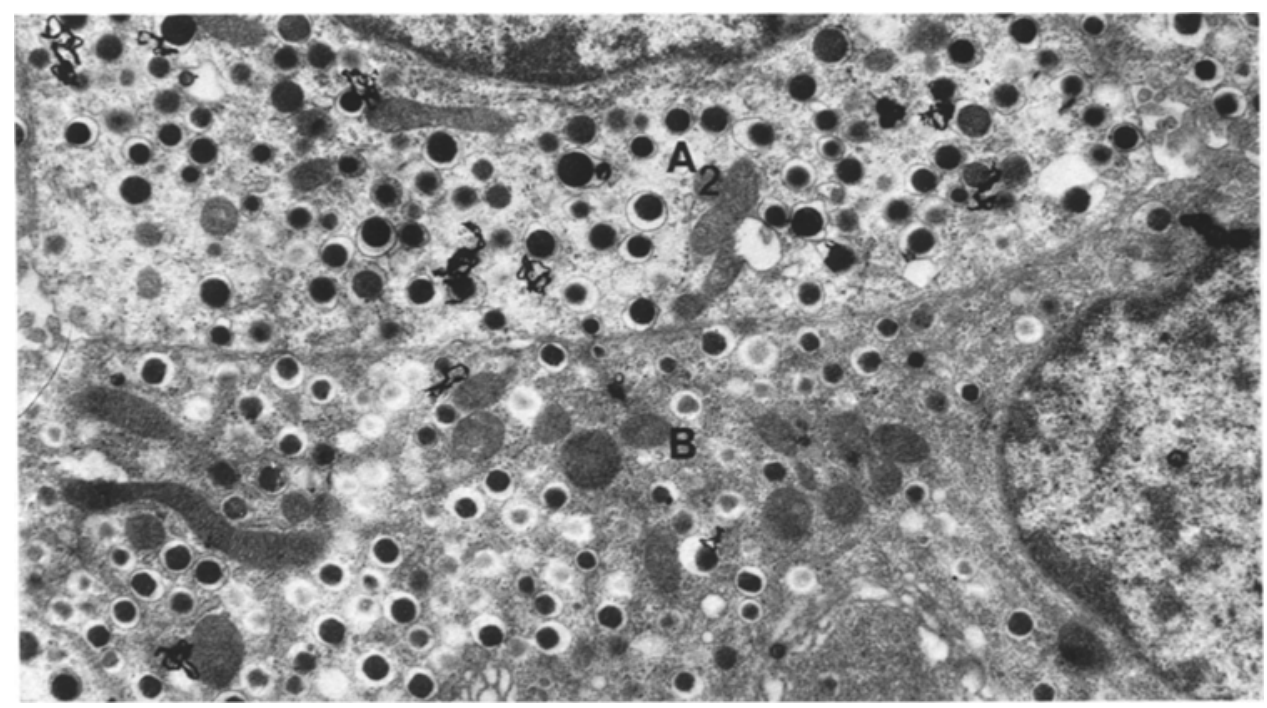

Fig. 7. Sixteen hours after ${ }^{3} \mathrm{H}-5$-HTP. Pretreatment with monoamine oxidase inhibitor. Autoradiographic silver grains over an $\mathrm{A}_{2}$ cell and a $\mathrm{B}$ cell. $\times 12000$

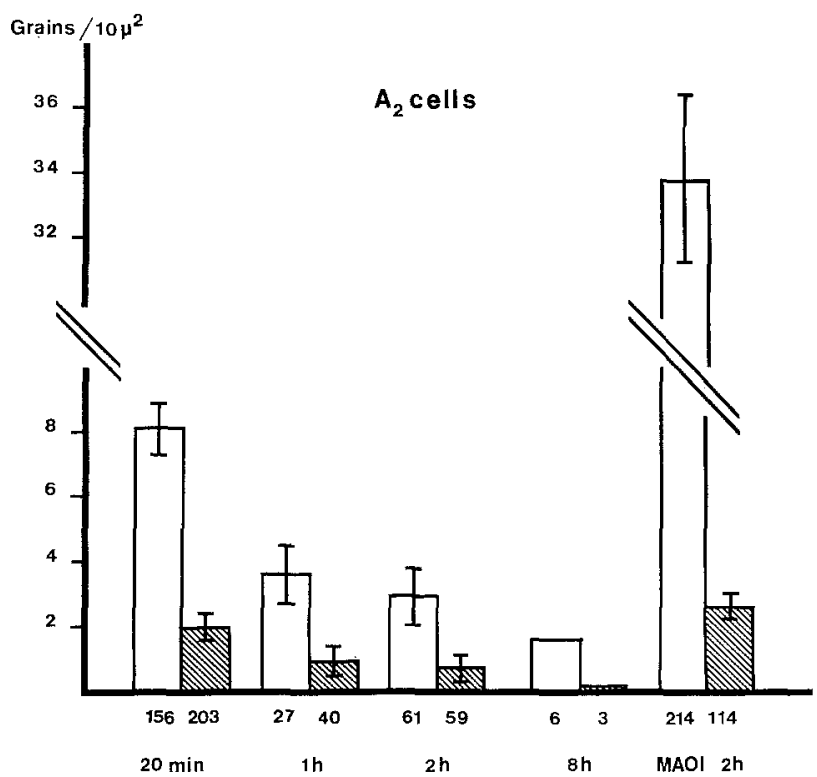

Fig. 8. Quantitative analysis of the distribution of autoradiographic silver grains over $\mathrm{A}_{2}$ cells at different times after the administration of ${ }^{3} \mathrm{H}-5$-HTT (mean values \pm S.E.M.). Open bars = specific granules. Hatched bars $=$ remaining parts of the cells. MAOI $=$ monoamine oxidase inhibition. The figures under each bar indicate the number of silver grains counted

$A_{1}$ cells. Over the $\mathrm{A}_{1}$ cells, very few silver grains were recorded at all times studied (Figs. 1, 10) and also after inhibition of MAO (Figs. 4-6). No consistent time-dependence could be observed in the labelling pattern; in some specimens the granules showed a

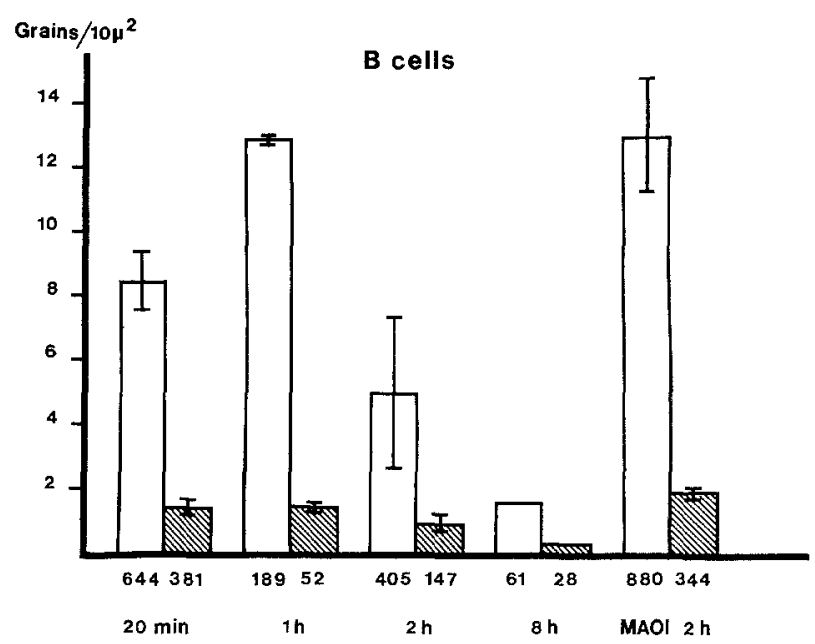

Fig. 9. Quantitative analysis of the distribution of silver grains over B cells at different times after the administration of ${ }^{3} \mathrm{H}-5-\mathrm{HTP}$. Symbols as in Fig. 8

(without differentiation between granules and nongranular cytoplasm) was about 0.5 grain $/ 10 \mu^{2}(20 \mathrm{~min}-$ $2 \mathrm{~h}$ ), and equalled that found over fibroblasts and vascular cells ("connective tissue cells") (Fig. 10). Calculated in a similar way the grain counts over $\mathrm{A}_{2}$ and $B$ cells were about 1.9 and 2.7 grains $/ 10 \mu^{2}$, respectively at $20 \mathrm{~min}$ (Fig. 10). The figures recorded for $A_{1}$ cells and non-endocrine cells were, however, dis- 
tinctly higher than the silver grain counts over the plastic embedding medium (background counts), which varied slightly in different preparations $(0.05-0.15$ grain $\left./ 10 \mu^{2}\right)$. All figures given are corrected for the background counts found in the different autoradiographio specimens.

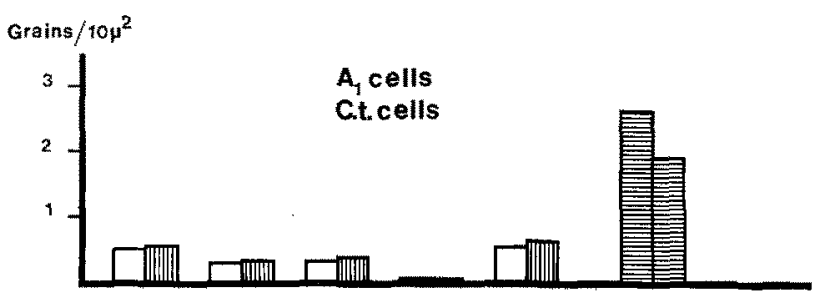

$20 \mathrm{~min}$ ith $2 \mathrm{~h}$ in MAOI2h $\mathrm{B}_{20} \mathrm{~A}_{20}$

Fig. 10. Quantitative analysis of silver grains over $A_{1}$ cells (open bars) and connective tissue cells (hatched bars). The bars denote the mean concentration of silver grains over all parts of the cells. $B_{20}$ and $A_{20}$ demonstrate the values for $B$ and $A_{2}$ cells, respectively, 20 minutes after

injection of label, when calculated in a similar way

In one mouse given reserpine prior to the administration of ${ }^{3} \mathrm{H}-5-H T P$ no radioactivity could be recorded in the endocrine pancreas with the autoradiographic technique used here. The grain counts over agranular cells were always very low.

\section{Discussion}

In the present electron-microscopic study of the mouse pancreas, 3 distinct granulated cell types could be distinguished in the islets of Langerhans. $A_{2}$ and $B$ cells, which have the ability to accumulate radioactivity following administration of ${ }^{3} \mathrm{H}-5-\mathrm{HTP}$, were identified by their typical granules $[3,4,24,26,28,33]$. $A_{1}$ cells, which were observed in all islets examined, were characterized by a peripheral localization in the islets, by an elongated cell shape and by the presence of dense cytoplasmic granules which had a varying shape. A prominent feature of $A_{1}$ cells was the apparent inability to accumulate radioactivity after administration of ${ }^{3} \mathrm{H}-5$-HTP.

On the light microscopic level, $A_{1}, A_{2}, B$ and agranular cells have been described in the mammalian pancreas $(22,23) . A_{1}$ cells are argyrophil as revealed by staining with a modification of Daverport's silver impregnation method $[22,23]$. Several authors $[12,19$, 34 ] consider the argyrophil cells to be closely related to the light-microscopic $\mathrm{D}$ cells $[2,35]$. Also ultram structurally defined D cells, characterized by granules of fairly low density, have been proposed as equivalent to the silver positive cells $[3,4,28]$. However, in the present study very few cells fitting earlier ultrastructural descriptions of $\mathrm{D}$ cells were encountered. In the mouse, the $A_{1}$ cells are described in light-microscopic studies as having a peripheral distribution in the islets, an elongated cell shape and occurring at a lower fre- quency than the $A_{2}$ cells, which are also peripherally distributed [23]. These observations are consistent with our electron-microscopical findings, and they corroborate the assumption that the $A_{1}$ cells as defined in the present study are equivalent to the cells denoted as $A_{1}$ by light microscopists.

A certain variation in the ultrastructure of the $A_{1}$ cell was noted. In typical cells the granules were polymorphous, but not infrequently cells were encount. ered in which the majority of the granules had a spherical shape. This may indicate that the $A_{1}$ cells as defined here consist of several subgroups, possibly with different functions. However, all cells defined as $A_{1}$ cells, irrespective of the morphology of their granules, displayed the inability to store monoamines as judged by electron microscopic autoradiography.

Concerning the $A_{2}$ cells, intercellular variations were observed in the size of the cytoplasmic granules. The implications of this observation, also made in earlier studies $[4,24]$, cannot be evaluated at present.

The finding that some cells apparently lack distinct secretory granules is in accordance with earlier light and electron microscopic observations $[1,4,24,26,35]$.

In studies with the fluorescence method of Falck and Hillarp [51], both DA and 5-HT have been demonstrated in pancreatic islets of several species, e.g. duck, pigeon, guinea pig, cat, pig, horse and monkey $[6-8,16,17]$. Great species differences exist with respect to the presence of histochemically demonstrable amines, as well as to their type and cellular distribution. In the adult mouse, rat and hamster the islets are practically devoid of fluorescent cells $[6,16)$. The fact that monoamines cannot be demonstrated in these species under normal conditions by the fluorescence method does not rule out the possibility that similar compounds may play a role in the normal metabolism of islets cells. It is for instance possible that such amines occur, but that they do not form fluorophores by condensation with formaldehyde, or that the concentration of amines is too low to give rise to any detect: able fluorescence. Furthermore, as demonstrated in the present and several earlier studies, 5-HTP and DOPA, the immediate precursors in the synthesis of 5 -HT and DA, are taken up by islet cells. Since inhibition of the decarboxylating enzyme abolishes the fluorescence reaction whereas inhibition of MAO enhances it, it seems very probable that the major products stored in islet cells are the monoamines formed from the administered aromatic amino acid precursors by the action of aromatic amino acid decarboxylase [6]. Also, studies employing light-mioroscopic autoradiography, on either chemically fixed [21] or frozen-dried tissue [32], are in accordance with this view.

By studying in vitro the washout of isotopes from pieces of various tissues taken from mice injected with labelled 5-HTP, Gershon and. Ross [20] were able to demonstrate that 5-HT was firmly bound in the tissues, contrary to the finding with 5-HTP and a metabolite, 5-HT-o-glucuronide. This binding of 5-HT remained 
after the application of chemical fixatives, preferably hypertonic glutaraldehyde in combination with osmium, whereas the amino acid and the metabolite were to a great extent washed out of the tissues. It was demonstrated that at least $80 \%$ of the original 5 - $\mathrm{HT}$ activity remained in the tissues at the end of the preparation procedure. The data presented by Gershon and Ross taken together with the observations, discussed above, in the fluorescence microscope after injection of monoamine precursors, seem to make the assumption legitimate that the majority of the silver grains observed in our autoradiographs represent 5-HT. As shown by the quantitative analysis of autoradiographic sections, the majority of the silver grains were associated with the specific granules of $A_{2}$ and $B$ cells. Since pretreatment with reserpine, which is known to hamper the binding of amines within storage structures but not the entry of monoamines or amino acids into cells, abolishes the autoradiographic reaction, it seems reasonable to assume that the radioactivity localized to the specific granules represents bound 5-HT. Furthermore, in mice pretreated with a decarboxylase inhibitor prior to the administration of ${ }^{3} \mathrm{H}-\mathrm{DOPA}$, there is no concentration of autoradiographic silver grains over the granules in $A_{2}$ and $B$ cells (unpublished observations), which shows that the formation of an amine by decarboxylation of the labelled amino acid is a prerequisite for the accumulation of silver grains over the specific granules. The compartmentalization of 5-HT within the granules is probably one main reason why the amine is retained in the tissue during the tissue preparation procedure.

At all times studied, a certain number of silver grains were always found associated with parts of the endocrine cells other than the specific granules. Some of this extragranular labelling was probably due to cross-scatter from the highly radioactive granules. However, silver grains were invariably found over structures remote from the granules. The nature of the compounds giving rise to this autoradiographic reaction is not evident, but two plausible interpretations are available. Firstly, it is very likely that some of the extragranular radioactivity represents labelled precursor amino acids, as it is known that glutaraldehyde fixation can retain about $25 \%$ of the free amino acids in tissues [30]. Secondly, it is also quite possible that 5-HT in the fixed tissue can be firmly associated with extragranular structures by binding to a protein as proposed for labelled norepinephrine in nerve cells [9].

Earlier studies in the fluorescence microscope [6] have demonstrated a higher and more prolonged retention of specific fluoreseence in peripherally located cells, probably $\mathrm{A}_{2}$ cells, than in $\mathrm{B}$ cells in mouse islets following injection of DOPA or 5-HTP. In the present study, on the other hand, the $A_{2}$ cells displayed a lower labelling than the $B$ cells at all times studied except for $20 \mathrm{~min}$. It was also found that a fairly great fraction of the silver grains over the $A_{2}$ cells were related to cellular structures other than the specific granules. The discrepancy between our findings and earlier light microscopic observations on frozen-dried tissue may indicate that in $A_{2}$ cells a considerable percentage of the monoamines is located in extragranular compartments. In tissues fixed with glutaraldehyde these extragranular amines are probably washed out of the cells to a certain extent, wheras freeze-drying retains practically all amines. However, it is also possible that a fraction of the monoamines in B cells is bound in a form not permitting the formation of a fluorophore, thus giving an impression of a higher monoamine content in $\mathrm{A}_{2}$ cells when studied in the fluorescence microscope.

The quantitative analysis of electron-microscopic autoradiographs demonstrated that the turnover of 5-HT in $A_{2}$ cells and $B$ cells differed. In $A_{2}$ cells the highest value of radioactivity in the specific granules was recorded already 20 min after the injection of label, whereas in $B$ cells the highest value was found at $1 \mathrm{~h}$. These data suggest that $A_{2}$ cells have a higher turnover rate of the amine formed, which is corroborated by the observation that MAO-inhibition had a more striking effect in $\mathrm{A}_{2}$ cells than in $\mathrm{B}$ cells. This observation also shows that MAO operates in both $A_{2}$ cells and $B$ cells, which is contradictory to the results of earlier histochemical studies in different mammalian species, in which MAO was found in B cells only [31].

As discussed above, the present study demonstrates a high labelling of the specific granules of $\mathrm{A}_{2}$ and $\mathrm{B}$ cells after administration of ${ }^{3} \mathrm{H}-5-\mathrm{HTP}$. Also endogenous 5-HT seems to have a similar localization in B cells, as demonstrated in the guinea pig with a cytochemical technique based on the formation of an electron-dense precipitate by the reaction between 5-HT, dichromate and glutaraldehyde [25].

An interesting observation made in the present investigation was the absence of autoradiographic reaction over the $A_{1}$ cells. This could be due to either the fact that monoamines are not formed at all in these cells or that there is a storage mechanism for monoamines which is different from that in $\mathrm{A}_{2}$ and $\mathrm{B}$ cells, permitting the washout of labelled amines. Fluorescence microscopic studies with the technique of Falck and Hillarp have not revealed with certainty monoamines in $A_{1}$ cells of mammalian islets [6].

The ability to store amines, either naturally or after the administration of the precursor amino acid, is widely distributed among endocrine cell systems [18, 29]. These various endocrine cells produce polypeptide or protein hormones and are ultrastructurally characterized by the presence of granules in the cytoplasm. In a recent study, 5-HT formed from exogenous 5-HTP was localized by electron microscopic autoradiography in the specific granules of the thyroid parafollicular cells, which are known to produce the polypeptide hormone calcitonin [13]. A granular localization of exogenous DA and 5-HT have also been seen in endocrine cells in the mouse gastrointestinal tract (unpublished observations). 
The present study thus demonstrates in $A_{2}$ and $B$ cells the localization of 5-H'T, formed from injected ${ }^{3} \mathrm{H}-5-\mathrm{H} T \mathrm{~T}$, in those cytoplasmic elements that are supposed to be the storage site for hormones or hormone precursors. In a subsequent paper [11] the possible functional implications of some of our morphological observations presented here will be discussed.

\section{References}

1. Bensley, R.R.: Studies on the pancreas of the guinea pig. Amer. J. Anat. 12, 297-388 (1911).

2. Bloom, W.: New type of granular cell in islets of Langerhans of man. Anat. Rec. 49, 363-371 (1931).

3. Caramia, F.: Electron microscopic description of a third cell type in the islets of pancreas of the rat. Amer. J. Anat. 112, 53-64 (1963).

4. Caramia, F., Munger, B.L., Lacy, P.E.: The ultrastructural basis for the identification of cell types in the pancreatic islets. I. Guinea pig. Z. Zellforsch. 67, $533-546(1965)$.

5. Caro, L.G., van Tubergen, R.P.: High-resolution autoradiography. I. Methods. J. Cell Biol. 15, $173-$ $188(1962)$.

6. Cegrell, L.: The occurrence of biogenic monoamines in the mammalian endocrine pancreas. Acta physiol. scand. suppl. 314 (1968).

7. - Falck, B.: A catecholamine storage in the pancreatic $\mathrm{A}_{2}$-cells of owl monkey (Aotes trivirgatus). Z. Zellforsch. 94, 530-533 (1969).

8. - - Hellman, B.: Monoaminergic mechanisms in the endocrine pancreas. In: Brolin, S.E., Hellman, B. Knutson F. (Eds.): The Structure and Metabolism of the Pancreatic Islets, pp. 429-435. London: Pergamon Press. 1964.

9. Descarries, L., Droz, B.: Intraneuronal distribution of exogenous norepinephrine in the central norvous system of the rat. J. Cell Biol. 44, 385-399 (1970).

10. Ekholm, R., Ericson, L.E.: Monoaminergic mechanisms in the exocrine pancreas of the mouse studied with electron microscopic autoradiography. J. Ultrastruct. Res. in press (1971).

11. - - Lundquist, I.: Monoamines in the pancreatic islets of the mouse. 5-hydroxytryptamine as an intracellular modifier of insulin secretion and the effect of monoamine oxidase inhibitors. Diabetologia in press.

12. Epple, A.: Zur vergleichenden Zytologie des Inselorganes. Zool. Anz. suppl. 27, 461-470 (1964).

13. Ericson, L.E.: Subcellular localization of 5-hydroxytryptamine in the parafollicular cells of the mouse thyroid gland. An autoradiographic study. J. Ultrastruct. Res. 31, 162-177 (1970).

14. - Uptake of ${ }^{3} \mathrm{H}-5$-hydroxytryptophan by noradrenergic nerves in the mouse pancreas as ovidenced by electron microscopic autoradiography. Z. Zellforsch. 113, $441-449$ (1971).

15. Falck, B., Hillarp, N.-A., Thieme, G., Torp, A.: Fluorescence of catecholamines and related compounds condensed with formaldehyde. J. Histochem. Cytochem. 10, 348-354 (1962).

16. - Hellman, B.: Evidence for the presence of biogenic amines in pancreatic islets. Experientia 19, 139-140 (1963).

17. - - A fluorescent reaction for monoamines in the insulin producing cells of the guinea pig. Acta endocrinol. (Kbh.) 45, $133-138$ (1964).

18. - Owman, Ch.: 5-hydroxytryptamine and related amines in endocrine cell systems. Advanc. Pharmacol. 6A, 211-231 (1968).
19. Fujita, T.: The identification of argyrophil cells of pancreatic islets with D-cells. Arch. histol. jap. 25, $189-197$ (1964).

20. Gershon, M.D., Ross, L.L.: Radioisotope studies of the binding, exchange and distribution of 5-hydroxytryptamine synthesized from its radioactive precursor. J. Physiol. 186, 451-476 (1966).

21. - - Location of sites of 5-hydroxytryptamine storage and metabolism by radioautography. J. Physiol. 186, 477-492 (1966).

22. Hellerström, C., Hellman, B.: Some aspects of silver impregnation of the islets of Langerhans in the rat. Acta endocrinol. (Kbh.) 35, 518-532 (1960).

23. - - Pettersson, B., Alm, G.: The two types of pancreatic A cells and their relation to the glucagon secretion. In: Brolin, S.E., Hellman, B., Knutson, F. (Eds.): The Structure and Metabolism of the Pancreatic Islets, pp. 117-130. London: Pergamon Press 1964.

24. Hoyos-Guevara, E. de: The pancreatic islet system of the mouse (mus musculus). Ultrastructural report of six new cell types. Z. Zellforsch. 101, 28-62 (1969).

25. Jaim-Echeverry, G., Zieher, L.M.: Electron microscopic cytochemistry of 5-hydroxytryptamine in the beta cells of guinea pig endocrine pancreas. Endocrinology 83, 917-923 (1968).

26. Lacy, P.E.: Electron microscopic identification of different cell types in the islets of Langerhans of the guinea pig, rat, rabbit and dog. Anat. Rec. 128, $255-261(1957)$.

27. Maunsbach, A.B.: Absorption of ${ }^{125}$ I-labelled homologous albumin by rat kidney proximal tubule cells. A study of microperfused single proximal tubules by electron microscopic autoradiography and histochemistry. J. Ultrastruct. Res. 15, 197-241 (1966).

28. Munger, B.L., Caramia, F., Lacy, P.E.: The ultrastructural basis for the identification of cell types in the pancreatic islets. II. Rabbit, dog and opossum. Z. Zellforsch. 67, 776-798 (1965).

29. Pearse, A.G.E.: Common cytochemical and ultrastructural characteristics of cells producing polypeptide hormones (the APUD series) and their relevance to thyroid and ultimobranchial $\mathrm{C}$ cells and calcitonin. Proc. roy. Soc. Lond. B. 170, 71-80 (1968).

30. Peters, T. Jr, Ashley, C.A.: An artefact in radioautography due to binding of free amino acids to tissues by fixatives. J. Cell Biol. 33, 53-60 (1967).

31. Petkov, P.: De l'activité monoaminooxydasique dans le pancreas de l'homme et de certain mammifières: rat blanc, cobaye, chat et lapin. Ann. Histochem. 10, $10,17-24(1965)$.

32. Ritzen, M., Hammarström, L., Ullberg, S.: Autoradiographic distribution of 5 -hydroxytryptamine and 5 -hydroxytryptophan in the mouse. Biochem. Pharmacol. 14, 313-321 (1965).

33. Sato, T., Herman, L., Fitzgerald, P.J.: The comparative ultrastructure of the, pancreatic islets of Langerhans. Gen. comp. Endocrinol. 7, 132-157 (1966).

34. Solcia, E., Sampietro, R.: On the nature of the metachromatic cells of pancreatic islets. Z. Zellforsch. 65, $131-138(1965)$.

35. Thomas, B.: Cellular components of the mammalian islets of Langerhans. Amer. J. Anat. 62, 31-57 (1937).
Dr. Lars E. Erieson
Department of Anatomy
University of Göteborg
Fack
S-400 33 Göteborg 33
Sweden 